\title{
Antiviral Compounds from Myxobacteria
}

\author{
Lucky S. Mulwa ${ }^{1,2}$ (i) and Marc Stadler ${ }^{1, *}$ (1) \\ 1 Department of Microbial Drugs, Helmholtz Centre for Infection Research and German Centre for Infectio \\ Research (DZIF), Partner Site Hannover/Braunschweig, Inhoffenstrasse 7, 38124 Braunschweig, Germany; \\ luckymulwa@gmail.com \\ 2 Department of Microbial Strain Collection (MISG), Helmholtz Centre for Infection Research (HZI), \\ Inhoffenstrasse 7, 38124 Braunschweig, Germany \\ * Correspondence: marc.stadler@helmholtz-hzi.de; Tel.: +49-531-6181-4240; Fax: +49-531-6181-9499
}

Received: 25 May 2018; Accepted: 17 July 2018; Published: 19 July 2018

check for

Abstract: Viral infections including human immunodeficiency virus (HIV), cytomegalovirus (CMV), hepatitis $B$ virus (HBV), and hepatitis $C$ virus (HCV) pose an ongoing threat to human health due to the lack of effective therapeutic agents. The re-emergence of old viral diseases such as the recent Ebola outbreaks in West Africa represents a global public health issue. Drug resistance and toxicity to target cells are the major challenges for the current antiviral agents. Therefore, there is a need for identifying agents with novel modes of action and improved efficacy. Viral-based illnesses are further aggravated by co-infections, such as an HIV patient co-infected with HBV or HCV. The drugs used to treat or manage HIV tend to increase the pathogenesis of HBV and HCV. Hence, novel antiviral drug candidates should ideally have broad-spectrum activity and no negative drug-drug interactions. Myxobacteria are in the focus of this review since they produce numerous structurally and functionally unique bioactive compounds, which have only recently been screened for antiviral effects. This research has already led to some interesting findings, including the discovery of several candidate compounds with broad-spectrum antiviral activity. The present review looks at myxobacteria-derived antiviral secondary metabolites.

Keywords: myxobacteria; antivirals; secondary metabolites; HIV; Ebola; hepatitis viruses

\section{Introduction}

Antimicrobial resistance (AMR) threatens the effective treatment, control and management of an increasing range of infections caused by viruses, bacteria, parasites and fungal pathogens [1]. Development of effective therapies to suppress human immunodeficiency virus (HIV) and hepatitis B virus (HBV) has been achieved with great success [2]. However, the medicines are not curative, and therefore more efforts in HIV and HBV drug discovery are directed toward longer-acting therapies or compounds with new mechanisms of action that could potentially lead to a cure or complete eradication of the viruses [2]. In 2010, an estimated 7-20\% of people starting antiretroviral therapy (ART) globally had drug-resistant HIV [3]. Some countries have recently reported levels of $15 \%$ amongst those starting HIV treatment, and up to $40 \%$ among people re-starting therapy [3]. Of great concern are the high levels of viral resistance towards nucleoside reverse transcriptase inhibitors (NRTIs) as recently found in Kenyan children [4]. In 2015, the World Health Organization (WHO) recommended that everyone living with HIV should start on antiretroviral treatment. Hence, increased ART resistance is expected as more people start ART [3]. The United States Food and Drug Administration (FDA) approved anti-HIV drugs are classified into eight classes according to modes of action [5]. The common side effects of Abacavir ${ }^{\circledR}$ and other NRTIs are that they can cause life-threatening side effects, including a serious allergic reaction, a build-up of lactic acid in the blood, 
and hepatotoxicity [6,7]. In fact, each drug class of the FDA approved anti-HIV drugs has side effects, and some are contra-indicated for co-infected patients with HIV and HBC or HCV [8]. On the other hand, all influenza A viruses circulating in humans were reported to be resistant to Amantadine ${ }^{\circledR}$ and Rimantadine ${ }^{\circledR}$, two essential antivirals for treatment of epidemic and pandemic influenza A. However, the frequency of resistance to Oseltamivir ${ }^{\circledR}$ another antiviral with different mode of action for treating influenza A remains low at 1-2\% [3]. Treatment failure of antivirals has been suggested to be caused by the emergence of recombinant viruses, drug resistance, and cell toxicity $[9,10]$. Compounds with a different mode of action can play an essential role in overcoming AMR. Viral disease such as influenza spreads fast and knows no borders, with the vast masses of people travelling all over the globe due to efficient transport systems. Hence, there is an urgent need for international collaboration to identify new antiviral agents with new modes of action and better efficacy.

Myxobacteria are well-known to be producers of biologically active secondary metabolites with novel carbon skeletons and new modes of action [11-13]. Many compounds isolated from myxobacteria have recently been found to have impressive antiviral activity. More so, some have been found to have an unusual broad-spectrum antiviral activity $[11,12,14]$.

\section{Myxobacteria}

Myxobacteria are $\delta$-proteobacteria belonging to the order Myxococcales. They are rod-shaped, Gram-negative bacteria that exhibit gliding motility and swarm on solid surfaces. Under nutrient-limiting conditions, they form species-specific fruiting bodies (Figure 1) [15]. Within these fruiting bodies, some vegetative cells convert to myxospores, which are desiccation-resistant and can survive over decades. Under appropriate conditions the spores germinate [16]. These soil-dwelling microorganisms have also been isolated from other habitats such as the bark of trees, oceans, freshwater lakes, and herbivore dung [15,17]. Myxobacteria have also been isolated from extreme environments such as desert soils [18]. Numerous unique classes of secondary metabolites have been isolated from myxobacteria, the majority of which are biogenetically derived from polyketide synthases (PKSs) and non-ribosomal peptide synthetases (NPRSs) or a hybrid of PKSs and NPRSs $[12,15,19,20]$. PKSs and NPRSs are enzymatic "assembly lines" of complex multi-step biosynthetic pathways for making compounds by catalysing the stepwise condensation of a starter unit with small monomeric building blocks [19]. The ability to produce unique metabolites is conferred by the creative biosynthetic pathways and the large genome of 9-14 Mb [21], consistent with the strengthening correlation between genome size and the extent of secondary metabolites produced [21-25]. In fact, the sequenced genomes of myxobacteria are the largest yet known from any bacterium [20-23,25]. In the last 35 years, over 100 new carbon skeleton secondary metabolites, with over 600 analogues, have been isolated from over 9000 strains of myxobacteria [12]. The metabolites exhibited antifungal, antibacterial, antimalarial, antitumor, and anti-immunomodulatory properties some with novel modes of action and have been reviewed extensively $[12,20,26]$. Microorganisms are valuable as producers of bioactive metabolites because they can be cultivated in bioreactors from as little as below $5 \mathrm{~mL}$ to large scales of over 100,000 L, making the production of natural products independent of season, locality, or climate [15]. Furthermore, conditions in a bioreactor are controllable to optimise production of the desired outcome. Particularly important as illustrated by Zeeck et al., 2002 in the 'OSMAC' (One Strain-Many Compounds) approach, which revealed that microorganisms do not exhaust their potential for producing metabolites under standard laboratory conditions [27]. 


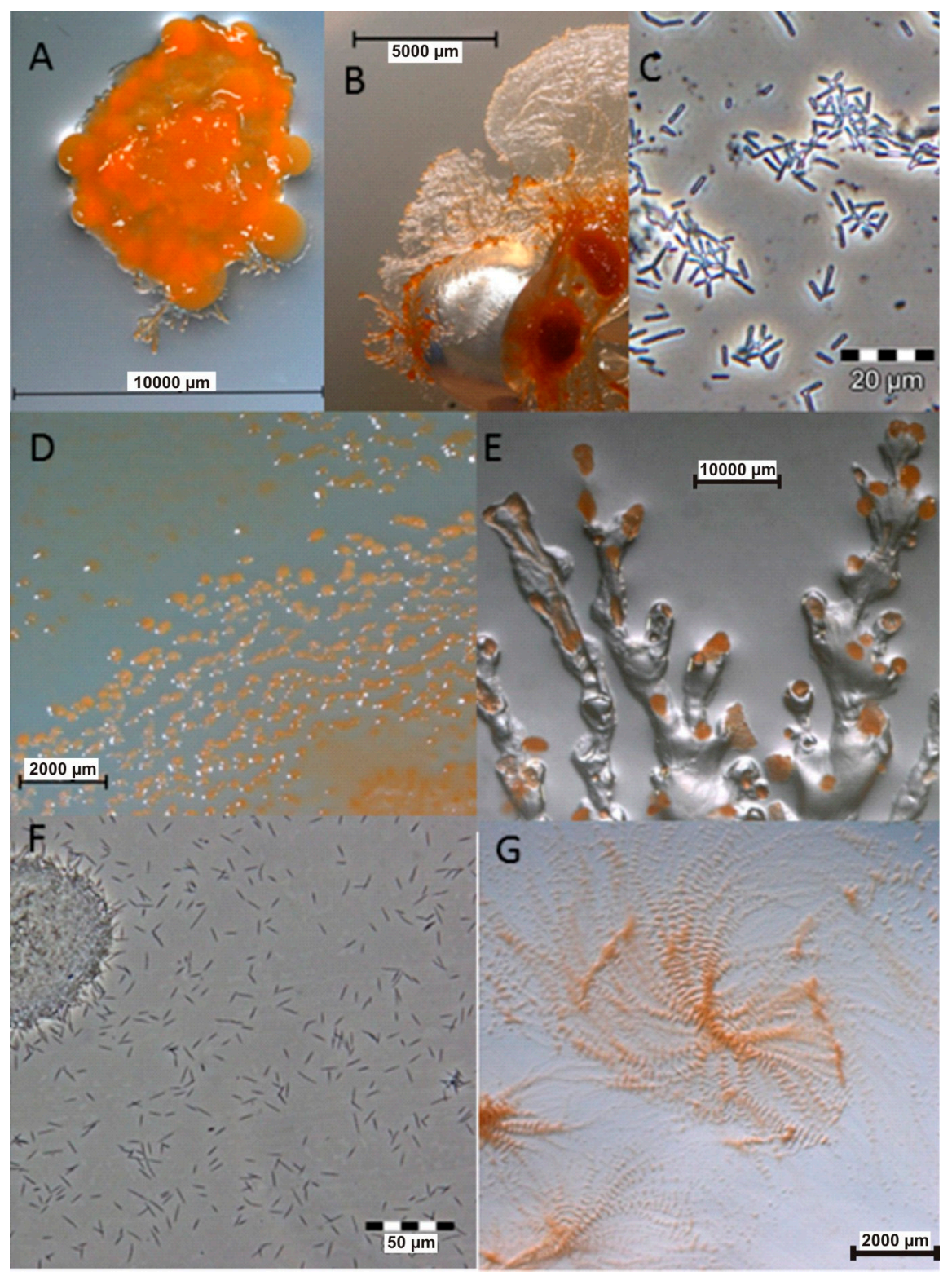

Figure 1. Images of myxobacteria. (A-C): Sorangium cellulosum; (A): Fruiting bodies; (B): Swarming on agar plate; $(\mathbf{C})$ : Cells from the liquid medium under the light microscope. (D-E): Images of the producers ofthiangazole (7), phenalamide $\mathrm{A}_{1}$ (8) and phenoxan (9), from agar plates; (D): Myxococcus stipitatus; (E): Polyangium species; (F-G): Angiococcus disciformis (strain An d30) producer of myxochelins; (F): culture under the light microscope from liquid media; $(\mathrm{G})$ : culture on agar plate. Images provided by Joachim Wink (HZI Braunschweig).

\section{Secondary Metabolites from Myxobacteria with Antiviral Activity}

\subsection{Human Immunodeficiency Virus (HIV)}

HIV is a lentivirus of the Retroviridae family. HIV targets immune cells, and reverse transcribes its single-stranded RNA (ssRNA) genome, integrating into the host chromosomal DNA. The virus uses high antigenic diversity and multiple mechanisms to avert recognition by the human immune system thus posing a challenge to host defences and treatment [28].

Various assays have been developed and used to identify molecules with anti-HIV activity. Some of the assays includes structure-based design of a small molecule CD4-antagonist with broad 
spectrum anti-HIV-1 activity [29], structure-based identification of small molecule antiviral compounds targeted to the gp41 core structure of the human immunodeficiency virus type 1 [30], and identification of HIV inhibitors by high-throughput (HTP) two-step infectivity assay [31]. The HTP assay has been used on myxobacterial-derived molecules with success due to the ability to screen a large number of molecules in a short period.

Sulfangolids, the first sulfate esters containing a series of secondary metabolites produced by several strains of Sorangium cellulosum, were isolated together with the structurally related macrolide kulkenon (5) [32]. Sulfangolid C (1), soraphen F (2), epothilon D (3), and spirangien B (4), showed impressive activity, with $\mathrm{EC}_{50}$ values in the $\mathrm{nM}$ range with a selectivity index value greater than 15 (SI > 15) in the high-throughput two-step infectivity assay [31]. Despite the impressive antiviral activity of 5, the SI is low because of toxicity. A search in the SciFinder database revealed dozens of analogues of soraphen and epothilone [33]. It may be promising to screen the large number of analogues in the soraphen and epothilone families to attempt to encounter more potent representatives with better SI values. The soraphens have been reported as acetyl-CoA carboxylate transferase inhibitors [34], while the epothilones stabilise microtubuli of macrophages in a similar manner as Taxol $^{\circledR}$ without showing taxol-like endotoxin activity $[35,36]$. In fact, the FDA-approved anticancer drug, Ixabepilone ${ }^{\circledR}$, is an epothilone B derivative [37]. Metabolites 3 and 4 are reported to decelerate the phosphorylation and degradation of inhibitor of kappa $\mathrm{B} \alpha(\operatorname{IkB} \alpha)[36,38]$. The compounds identified as preliminary hits for anti-HIV included 1-5 (Table 1, Figure 2) [31]. Rhizopodin (6), from Myxococcus stipitatus was identified as interesting in the two step HTP assay, likely because of its mode of action [31]. HIV cell-to-cell transmission is the primary route of HIV infection in naive cells in vivo. Actin filaments are known to be essential for virological synapse formation, therefore, virus synapses are interfered by $\mathbf{6}$, which is a known actin inhibitor. Disorazol, tubulysin and stigmatellin variants were also reported to have mild anti-HIV activity [31]. Thiangazole (7), phenalamide $\mathrm{A}_{1}$ (8), and phenoxan (9) isolated from two strains of Polyangium sp. and Myxococcus stipitatus strain Mx s40 were reported to have anti-HIV activity (Figure 2) [39]. They all revealed high activity by suppressing HIV-1-mediated cell death in the MT-4 cell assay with $\mathrm{EC}_{50}$ values of $\mathbf{9}$ and 8 in the nanomolar range, whereas thiangazole (7) had an impressive $\mathrm{EC}_{50}$ value in the picomolar range, making it a possible lead compound for anti-HIV therapy (Table 2, Figure 2) [39]. In another assay involving measuring ATP levels as a parameter of cell viability of TZM-bl cells aetheramide A (10a) and aetheramide B (10b) isolated from the recently described genus Aetherobacter, inhibited HIV-1 infection with $\mathrm{IC}_{50}$ value of 0.015 and $0.018 \mu \mathrm{M}$, respectively [40-42]. Concurrently, the aetheramides were reported to be moderately antifungal and cytotoxic [41]. The chemical structures of $\mathbf{1 0 a}$ and $\mathbf{1 0 b}$ are rare, containing a polyketide moiety and two amino acid residues, thus forming a new class of antivirals [40-42]. This discovery of new antivirals from the recently described myxobacteria genus, Aetherobacter, represents an example of the enormous biosynthetic capabilities of myxobacteria and their importance to drug discovery efforts [42]. Ratjadon A (11), an $\alpha$-pyrone metabolite isolated from Sorangium cellulosum (strain Soce 360), was reported to inhibit HIV infection by blocking the Rev/CRM1-mediated nuclear export pathway $[43,44]$. The CRM1-Rev complex is an attractive target for the development of new antiviral drugs because the nuclear export of unspliced and partially spliced HIV-1 mRNA is mediated by the recognition of a leucine-rich nuclear export signal (NES) in the HIV Rev protein by the host protein CRM1/Exportin1 [44]. Despite 11 being reported to exhibit a strong anti-HIV activity, it has a low selectivity due to toxic effect. The low SI value limits the potential use of $\mathbf{1 1}$ as a therapeutic drug. More studies with derivatives of $\mathbf{1 1}$ need to be done. It is important to observe that different assays were used to screen for anti-HIV compounds. There is a need therefore for a standardised method to be able to adequately compare the anti-HIV activity of those compounds that have been identified as preliminary hits. Equally important is an evaluation of the mechanism of action on viruses in comparison to the mechanism of action on bacteria or fungi. Investigation for synergism between the identified anti-HIV compounds for possible use at a lower concentration to improve the selectivity index of the metabolites should be looked into in the future. Even the active metabolites that cannot realistically be further 
developed as drug candidates because they are too toxic, could be used as biochemical tools to attain a better understanding of the invasion mechanism of HIV, or for development of synthetic analogues that mimic these compounds without causing toxicity.

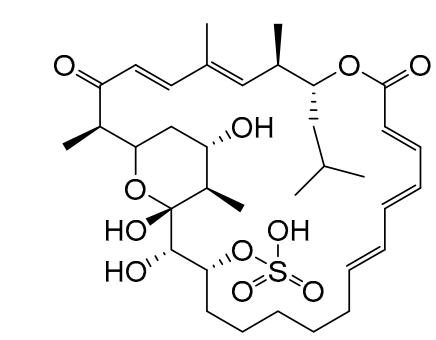

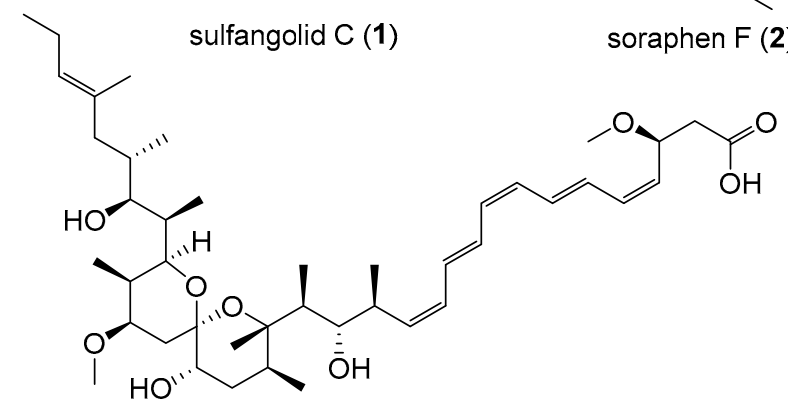

spirangien $B(4)$<smiles>COCC(/C=C/C=C/CC(O)CC(=O)OC(CC(OC)C(C)C)C(C)(C)C(O)Cc1nc(C(C)C)co1)OC</smiles>

rhizopodin (6)<smiles>C=C/C(C)=C\[C@H](C)[C@H](O)/C(C)=C/[C@H](C)CCc1ccccc1</smiles>

aetheramide $\mathrm{A}(\mathbf{1 0 a})$

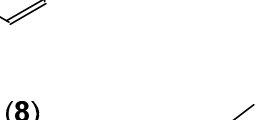

(8)<smiles>CCC(C)NC(C)=O</smiles>

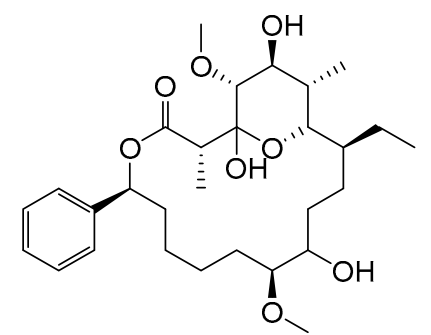

soraphen F (2)<smiles>CC/C(C)=C\CC(OC(=O)CC(O)C(C)(C)C(=O)C(C)C(O)C(C)CCC/C(C)=C/c1csc(C)n1)/C(C)=C/c1csc(C)n1</smiles>

epothilon D (3)

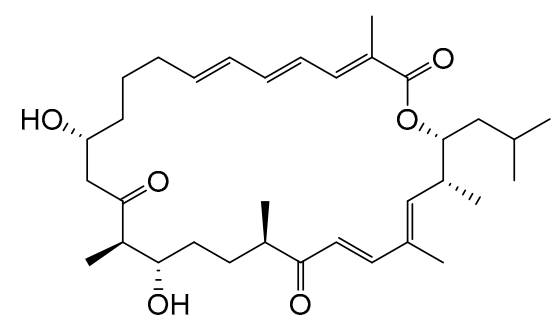

kulkenon (5)<smiles>CCCC(=O)C(C)C(C/C=C/N(C)C(=O)OCCCCOc1ccccc1)OC</smiles>
thiangazole (7)<smiles>CCc1c(-c2coc(CC/C(C)=C/c3ccccc3)n2)oc(OC)c(C)c1=O</smiles><smiles>C/C=C/CC</smiles>

aetheramide $B$ (10b)

Figure 2. Myxobacterial-derived compounds with activity against human immunodeficiency virus (HIV). 
Table 1. Preliminary anti-HIV hits from a high-throughput two-step infectivity assay [31].

\begin{tabular}{ccccc}
\hline Compound & $\mathbf{M W}^{\mathbf{1}}$ & $\mathbf{E C}_{\mathbf{5 0}}(\boldsymbol{\mu M})$ & $\mathbf{C C}_{\mathbf{5 0}}(\boldsymbol{\mu M})$ & SI $^{* *}$ \\
\hline Nevirapine * $^{*}$ & 266 & 0.07 & 81.8 & $>10^{3}$ \\
sulfangolid C (1) & 682 & 0.41 & 8.18 & 20.2 \\
soraphen F (2) & 522 & 0.30 & 5.02 & 16.5 \\
epothilon D (3) & 491 & 0.0005 & 0.012 & 24.4 \\
spirangien B (4) & 717 & 0.007 & 0.35 & 52 \\
kulkenon (5) & 734 & 0.07 & 0.36 & 5.3 \\
\hline
\end{tabular}

* Control, ${ }^{1}$ Molecular weight, $\mathrm{EC}_{50}$ : effective concentration; $\mathrm{CC}_{50}$ : cytotoxic concentration; ** Selectivity Index $=\mathrm{CC}_{50} / \mathrm{EC}_{50} . \mathrm{EC}_{50}$ is the concentration of a drug or metabolite which induces a response halfway between the baseline and maximum after a specified exposure time or gives the desired effect to $50 \%$ of test subjects. While $\mathrm{SI}$ is a comparison of the amount of a drug or metabolite that causes the desired effect to the amount that causes death or toxicity. Metabolites with a low $\mathrm{EC}_{50}$ and a high SI values are good drug candidates.

Table 2. Anti-HIV-1 activities of compounds derived from myxobacteria by MT-4 cell assay [40,41].

\begin{tabular}{ccccc}
\hline Compound & $\mathbf{M W}^{\mathbf{1}}$ & $\mathbf{T x}^{\mathbf{2}}(\mathbf{n M})$ & $\mathrm{AE}^{\mathbf{3}}(\boldsymbol{\mu M})$ & $\mathbf{S I}^{* *}$ \\
\hline AZT $^{*}$ & 267 & 250,000 & 25 & $10^{4}$ \\
thiangazole (7) & 539 & $>4700$ & 0.0047 & $>10^{6}$ \\
phenalamide A $A_{1}(8)$ & 491 & 102,000 & 1.02 & $10^{5}$ \\
Phenoxan (9) & 379 & $>6600$ & 6.6 & $>10^{3}$ \\
\hline
\end{tabular}

* azidothymidine Control, ${ }^{1}$ Molecular weight, ${ }^{2}$ Toxicity (Tx) is the lowest toxic concentration (nM) of the compound in the MT-4 cell assay, ${ }^{3}$ Antiviral efficacy (AE) is given as the lowest effective concentration $(\mu \mathrm{M})$ of the compound at which $100 \%$ prevention of the virus-mediated cytopathogenicity was observed in the MT-4 cell assay, ** Selectivity Index $=\mathrm{Tx}(\mathrm{nM}) / \mathrm{AE}(\mu \mathrm{M})$.

\subsection{Human Cytomegalovirus (HCMV)}

HCMV belongs to the $\beta$-herpesvirus family, with a high prevalence, infecting up to $80 \%$ of the general population usually asymptomatic in healthy people [45]. Diseases associated with HCMV include glandular fever and pneumonia. HCMV is also an important pathogen in organ transplant patients responsible for significant morbidity and mortality in organ transplant recipients, and a major cause of disease in patients with HIV infection [46]. HCMV infections in newborns may result in hearing loss, mental retardation and palsy [47]. The available FDA-approved therapeutic options for HCMV infection include ganciclovir, foscarnet, cidoforvir, and fomivirsen [48]. These drugs have different mechanisms of actions or applications, and represent the successes that had been made against the challenges of HCMV [48-50]. Several anti-HCMV drugs were reported to have low potency, poor oral bioavailability, and adverse side effects [50]. Moreover, drug resistance strains were reported to emerge [51]. Hence, there has been a renewed interest in search of new inhibitors of HCVM [50,51]. Of greater concern is the increase in the number of people living with transplanted organs, and the increase in HIV infected people [52]. Technological advancements have enabled organ transplants to be more accessible while the increase in HIV-infected individuals is due to new retroviral therapies that have converted HIV infection to chronic disease as infected people live longer, leading to increased cases of HCMV infection [52]. In 2011, the first case of HCMV-treated with AIC246, a novel anti-CMV compound that targets the viral terminase complex and remains active against virus resistant to DNA polymerase inheritors was reported [53], which represents a good example of the renewed interest for HCMV inhibitors [53]. Almost 60 patents claiming novel agents for the treatment of HCMV were launched from January 1996 to 2000, but so far none of these projects has led to the approval of an anti-HCMV drug [49]. However, the recent FDA approval of letermovir (Figure 3), providing a long-awaited alternative for preventing cytomegalovirus infection in allogeneic hematopoietic stem cell transplant recipients [54] is very encouraging. 


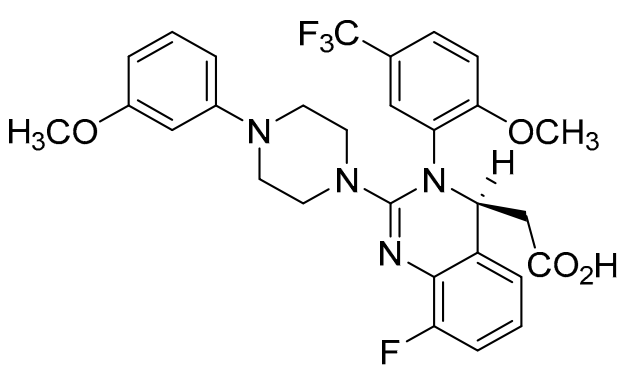

letermovir (19)

Figure 3. PREVYMISTM (letermovir) a recently (2017) FDA-approved drug for the prevention of Human cytomegalovirus (HCMV) infection and disease in organ transplant patients.

A class of myxobacterial compounds, myxochelin, belonging to a larger group of natural products, siderophores, were isolated from several strains of myxobacteria $[53,55]$. Siderophores are secondary metabolites produced by some microorganisms under iron-limiting conditions, and enhance the uptake of iron [56]. Other siderophores isolated from myxobacteria includes nannochelins and hylachelins. Various studies have revealed myxochelins to be potent antitumour agents [55,57-59]. The antitumour activity was demonstrated to be caused by inhibition of human 5-lipoxygenase (5-LO) [58]. Surprisingly the inhibition of 5-LO by myxochelins was found not correlating with the iron affinities [58]. The enzyme 5-LO is responsible for the catalysis of two initial steps in the biosynthesis of leukotriens, starting from arachidonic acid [58]. Leukotriens are well-known mediators of a variety of allergic reactions such as inflammatory, rheumatic arthritis, allergic rhinitis and cardiovascular diseases [58]. Importantly, 5-LO pathways were associated with cancer proliferation, hence explaining the observed strong anticancer activity of myxochelin $[58,60]$. Nannochelins are reported to have no significant antimicrobial activity [24].

Myxochelin A (12a) was initially isolated from the culture broth of Angiococcus disciformis (strain An d30). Later on, myxochelins B (12b), C (12c), D (12d), E (12e), and F (12f) were isolated and also synthesised (Figure 4) [60,61]. The corresponding biosynthetic gene clusters have been identified in Stigmatella aurantiaca (Sga 15), and Sorangium cellulosum (Soce 56) [62]. Additional siderophores have been isolated from Nannocystis exedens (21a-21c) and Hyalangium minutum (20a-20c) [63,64]. Myxochelin C (12c) inhibited HCMV with an $\mathrm{IC}_{50}$ value of $0.7 \mu \mathrm{g} / \mathrm{mL}[46,53]$. It could in future become feasible to test others among the over 500 different siderophores that are known to science [65]. In particular, the known myxobacterial-derived siderophores, such as nannochelins (21a-21c), hylachelins (20a-20c), and all the other myxochelin analogues (Figure 4) should be screened for various antiviral activities, especially anti-HCMV, and should be studied for structure activity relationship for possible discovery of more potent antivirals.

\subsection{Ebola Virus Disease (EVD)}

Ebola haemorrhagic fever is caused by the Ebola virus (EBOV), a single stranded RNA enveloped virus belonging to the family Filoviridae. EVD first appeared in 1976 in two simultaneous outbreaks, one in Nzara, South Sudan, and the other in Yambuku, the Democratic Republic of Congo. The latter occurred in a village near the Ebola River, from which the disease takes its name [65,66]. EVD case fatality rate is around $50 \%$, with different cases from $25 \%$ to $90 \%$ fatality in past outbreaks reported [65]. Furthermore, EBOV is known to persist in immune-privileged sites, such as testicles, inside of the eye, and central nervous system, and in some people who have recovered from EVD [65]. The effect of the persistence is yet to be known [66]. 
<smiles>O=C(NCCCC[C@H](CO)NC(=O)c1cccc(O)c1O)c1cccc(O)c1O</smiles>

myxochelin A (12a)<smiles>N[C@@H](CCCCNC(=O)c1cccc(O)c1O)CNC(=O)c1cccc(O)c1O</smiles>

myxochelin B (12b)<smiles>O=C(NCCCC[C@@H](CNC(=O)c1cccc(O)c1O)NC(=O)c1cccc(O)c1O)c1cccc(O)c1O</smiles>

myxochelin C (12c)<smiles>O=C(NCC[C@@H](CNC(=O)c1cccc(O)c1O)NC(=O)c1cccc(O)c1O)c1cccc(O)c1O</smiles>

myxochelin $D(12 d)$

myxochelin $E$ (12e)

myxochelin B (12f)

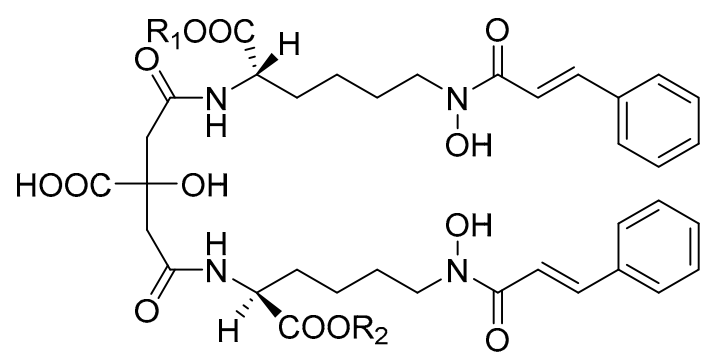

nannochelin $\mathrm{A}$ (21a) $\mathrm{R}_{1}=\mathrm{R}_{2}=\mathrm{CH}_{3}$

hyalachelin $\mathrm{A}$<smiles>[R]C1c2ccc(O)c(O)c2C(=O)N([C@H](CN)CCCCNC(=O)c2cccc(O)c2O)[C@@]1(O)C(=O)O</smiles>

nannochelin $B(21 b) \mathrm{R}_{1}=\mathrm{CH}_{3}, \mathrm{R}_{2}=\mathrm{H}$

nannochelin $C(21 \mathrm{c}) \mathrm{R}_{1}=\mathrm{R}_{2}=\mathrm{H}$

hyalachelin $C(20 c) R=$<smiles>Cc1ccc(O)cc1</smiles><smiles>Cc1ccccc1</smiles><smiles>Cc1c[nH]c2ccccc12</smiles>

Figure 4. Myxobacterial-derived siderophores.

The re-emergence of Ebola occurred in West African countries causing 11,308 deaths leading to the WHO on 8 August 2014, declaring the epidemic to be an international public health emergency [66]. An experimental Ebola vaccine called rVSV-ZEBOV has been reported to show high protection against EVD [67]. No drug or licensed vaccine currently exists; hence there is an urgent need for drugs that inhibit entry or multiplication of EDV [62,67]. Developing an assay to test compounds for anti-EBOV poses a significant challenge because of the cost of equipment for the high risk, Biosafety S4 organism, 
involved [66]. However, various metabolites from myxobacteria were screened for EBOV inhibition by an assay with a surrogate system using Ebola envelope glycoprotein GP-pseudotyped lentiviral vectors (Figure 5) [67]. GP-pseudotype lentiviral vectors were used as tools to investigate the entry process of the viruses, enabling studies without the need of using the native Ebola virus reducing the safety level from the highest level 4 to level 2 [67]. The same analysis was conducted with vesicular stomatisis virus (VSV)-G-pseudotyped vectors to determine the EBOV-specificity of the inhibitory function of the compounds. Chondramides $(\mathbf{1 3 a} \mathbf{- 1 3} \mathbf{d})$ were reported to inhibit EBOV-GP-mediated transduction with impressive $\mathrm{IC}_{50}$ values of 24-42 nM. The VSV-G-mediated transduction was less efficient, with an $\mathrm{IC}_{50}$ value of 55-111 nM [66]. Chondramides (13a-13d), a class of compounds known to interfere with actin, were isolated from a myxobacterium belonging to the genus Chondromyces [68]. Members of the genus Chondromyces belong to those myxobacteria known to synthesise two or more chemically unrelated secondary metabolites with different mechanisms of action [69]. Other promising hits were the noricumazoles, a family of polyketides from Sorangium cellulosum. Noricumazole A (14a) was found to inhibit EBOV-GP with an $\mathrm{IC}_{50}$ value of $0.33 \mu \mathrm{M}$. In fact, 14a was found to be EBOV-GP specific and showed no significant inhibition against (VSV)-G-pseudotyped vectors [67]. Noricumazoles are known to be potassium channel blockers with 14a known to be highly toxic while the derivatives, 14b and 14c, are equally active with lower toxicity $[67,70]$. The screening of myxobacterial natural compounds library resulted in the identification of inhibitors of EBOV-GP pseudotyped vectors, chondramides and noricumazole, whose mechanism of action is actin-stabilising and the channel blockers respectively [67]. These metabolites will give insights into the EBOV infection mechanism, rather than being used as drugs, because the modes of actions are expected to have side effects. However, the lower toxicity of $14 b$ and 14c, which are derivatives of 14a, is exciting and qualifies 14a to be considered as a lead structure for the development of EBOV inhibitors.<smiles>[R2]C(CC(C(=O)NC(c1ccc(O)cc1)C([R])C(=O)OC(C)C(C)C=C(C)CC(C)C(=O)NC(C)C(=O)Nc1ccccc1)N(C)C(=O)C(C)C)=C([R2])NC</smiles>

13

chondramide $\mathrm{A}$ (13a) $\mathrm{R}_{1}=\mathrm{OCH}_{3}, \mathrm{R}_{2}=\mathrm{H}$ chondramide $\mathrm{B}(13 \mathrm{~b}) \mathrm{R}_{1}=\mathrm{OCH}_{3}, \mathrm{R}_{2}=\mathrm{Cl}$ chondramide $\mathrm{C}(13 \mathrm{c}) \mathrm{R}_{1}=\mathrm{H}, \quad \mathrm{R}_{2}=\mathrm{H}$ chondramide $D(\mathbf{1 3 d}) \mathrm{R}_{1}=\mathrm{H}, \quad \mathrm{R}_{2}=\mathrm{Cl}$<smiles>[R2]O[C@H](/C=C/c1coc(C[C@H](O)[C@@H](C)CC)n1)[C@@H](C[C@@H]1Cc2ccc(C[C@@H](C)CC)c(O)c2C(=O)O1)O[R20]</smiles>

14

noricumazol $A$ (14a) $\mathrm{R}_{1}=\mathrm{H}, \mathrm{R}_{2}=\mathrm{H}$

noricumazol $B$ (14b) $R_{1}=H, R_{2}=$ Alpha-D-arabino-Furanosyl noricumazol C (14c) $\mathrm{R}_{1}=$ Beta-D-arabino-gluco-Pyranosyl, $\mathrm{R}_{2}=\mathrm{H}$

Figure 5. Structures of myxobacterial-derived compounds with activity against Ebola virus (EBOV). Chondramides (13a-d) are known to be actin inhibitors, while noricumazols $(\mathbf{1 4 a}-\mathbf{c})$ are known potassium channel inhibitors [70,71].

\subsection{Hepatitis C Virus}

$\mathrm{HCV}$ is an enveloped, single-stranded RNA virus with positive polarity (ss (+) RNA). HCV is transmitted by blood-to-blood contacts, such as through intravenous injections, blood transfusion, and various exposures to blood contaminants. It can also be transmitted by contact with bodily fluids including saliva or semen of an infected person [72]. By 2015, there were 71 million people infected with HCV globally [73]. HCV and hepatitis B virus (HBV) infection are the major causes of hepatocellular 
carcinoma (HCC), associated with cirrhosis [74]. Currently, no products are available to prevent HCV infection. There are some drugs available that can cure HCV infection [75]. However, treatment is complicated by HIV-HCV/HBC co-infections with drug-drug interactions between anti-HIV and anti-HCV drugs, resulting in serious side effects and can lead to the death of patient [8]. The discovery of broad-spectrum antivirals may play an essential role in overcoming this challenge.

The recently isolated compounds from Labilithrix luteola, labindoles A (15a), and B (15b) have been reported to have moderately inhibited HCV (Figure 6) [75]. Interestingly the labindoles were said to have no cytotoxicity, anti-bacterial or antifungal activities. 3-chloro-9H-carbazole (17) and 4-hydroxymethyl-quinoline (18) also isolated from Labilithrix luteola were reported to have a strong inhibition of HCV [75]. Soraphens are a family of polyketide-derived macrolactones comprising over 50 metabolites known for strong antifungal activity [76]. However, recent studies have suggested that soraphen A (16) inhibits HCV replication in HCV cell culture models expressing subgenomic and full-length replicons as well as a cell culture-adapted virus with an $\mathrm{IC}_{50}$ value of $5 \mathrm{nM}[11,77]$. The HCV assay involved the development of subgenomic replicons that replicate autonomously in the human hepatoma cell line Huh-7 to be able to screen for anti-HCV activity. The subgenomic replicons are genetic materials from $\mathrm{HCV}$, which represent the actual invasion and replication of $\mathrm{HCV}$ on the liver cells [75]. Furthermore, $\mathbf{1 6}$ is known to depolymerise the acetyl-CoA carboxylase (ACC) complexes into less active dimers [77]. The mechanism of action of $\mathbf{1 6}$ is a valuable probe to study the roles of ACC polymerisation and enzymatic activity in viral pathogenesis [77]. Various minor structure alterations of $\mathbf{1 6}$ did not affect the antiviral activity [11]. Owing to the fact that soraphens inhibit both $\mathrm{HIV}$ and $\mathrm{HCV}$, it has been proposed that the broad-spectrum activity of $\mathbf{1 6}$ could be due to targeting commonly used host factors or pathways necessary for viral replication [78]. Another recently isolated myxobacteria-derived secondary metabolite, lanyamycin (22) from Sorangium cellulosum (strain Soce 481) moderately inhibited HCV with $\mathrm{IC}_{50}$ value of $11.8 \mu \mathrm{M}$ [78]. The macrolide, 22, is closely related to the bafilomycins, a class of secondary metabolites from actinobacteria [79]. Interestingly bafilomycin A was previously shown to possess good activity $\left(\mathrm{IC}_{50}\right.$ value of $0.1 \mathrm{nM}$ ) against influenza $A$ virus, which is below its cytotoxic levels [80]. Screening of $\mathbf{2 2}$ for activity against influenza A virus and other pathogenic viruses, and studying the mode of action would be interesting.

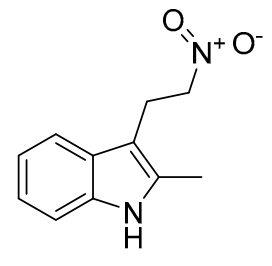

labindole $A(15 a)$<smiles>Cc1[nH]c2ccccc2c1/C=C/[N+](=O)[O-]</smiles>

labindole B (15b)

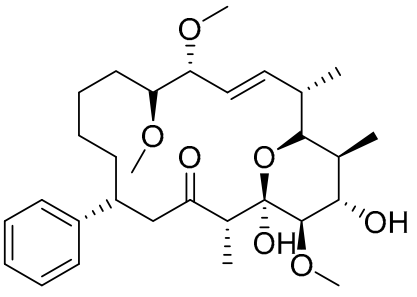

soraphen $A(16)$<smiles>Clc1ccc2[nH]c3ccccc3c2c1</smiles>

3-chloro-9H-carbazole (17)<smiles>OCc1ccnc2ccccc12</smiles><smiles>[CH]N(C(=O)C(CC)C(=O)c1ccccc1)[C@@H](O)C(O)C(C)C(=O)C(C)C(O)CC(=O)/C(C)=C/CC(OC)OC(=O)/C(=C/C(C)=C/[C@H](C)[C@@H](O)[C@@H](C)C/C=C/C=C/C)OC</smiles>

4-hydroxymethyl-quinoline (18)

lanyamycin (22)

Figure 6. Compounds with activity against Hepatitis C Virus. 


\section{Conclusions}

The reported antivirals discoveries call for more screening of myxobacterial-derived compounds, especially against other medically important viruses. Myxobacteria have demonstrated to be creative producers of molecules that can have valuable applications as possible lead structures for the development of antiviral drugs. Some broad-spectrum antivirals such as soraphen A could be of interest for the possibility of treating co-infection cases. Further, the possibility of using these myxobacteria derived secondary metabolites for treating both opportunistic infections and the HIV could be explored. The challenge of some compounds being toxic can be approached by structure modification for possibility of reducing toxicity while maintaining efficacy, as observed with the analogues of soraphen and noricumazoles. Moreover, some metabolites found to have potent antiviral activity may not be used as drugs themselves, due to toxicity, but they can serve as excellent tools to study and understand the viral invasion. This valuable information can be used to select other metabolites with similar mechanisms of action or structural modification of the compounds, to reduce their toxicity without substantially altering the activity. This ability of myxobacteria to produce such a vast number of secondary metabolites is most likely brought about by many years of evolution to adapt to survival in an ecological condition of competitive existence in the presence of competitors and invaders such as fungi, bacteriophages, and other bacteria. A recent comprehensive study involving molecular phylogeny with HPLC-MS profiling has revealed an unparalleled diversity of metabolites, along with strong correlations of the metabolite production to the phylogenetic position of the corresponding producer organisms [81]. Therefore, it appears promising to isolate more myxobacteria that represent novel genera and species from unexplored environments and screen them systematically for the production of further unique compounds with antiviral activities.

Author Contributions: Draft Preparation, L.S.M.; Editing of manuscript, M.S.

Funding: L.S.M. was supported by a Ph.D. grant from the DAAD-NACOSTI Scholarship funding program number (2014) 57139945 (91530969).

Acknowledgments: L.S.M. is highly indebted to DAAD-NACOSTI for the PhD Scholarship and TSC-Kenya for study leave. We are grateful to Joachim Wink and the technical staff of the HZI, Wera Collisi, Aileen Gollasch, Stephanie Schulz, Birte Trunkwalter and Klaus-Peter Conrad for the images of myxobacteria.

Conflicts of Interest: The authors declare no conflict of interest.

\section{References}

1. Nübel, U. Emergence and spread of antimicrobial resistance: Recent insights from bacterial population genomics. In How to Overcome the Antibiotic Crisis-Facts, Challenges, Technologies E Future Perspective; Stadler, M., Dersch, P., Eds.; Springer: Berlin, Germany, 2017; Volume 398, pp. 35-53.

2. Blair, W.; Cox, C. Current Landscape of Antiviral Drug Discovery. F1000 Rev. 2016, 5, 1-7. [CrossRef] [PubMed]

3. World Health Organization. Antimicrobial resistance. Available online: http://www.who.int/en/newsroom/fact-sheets/detail/antimicrobial-resistance (accessed on 18 May 2018).

4. Dziuban, E.J.; DeVos, J.; Ngeno, B.; Ngugi, E.; Zhang, G.; Sabatier, J.; Wagar, N.; Diallo, K.; Nganga, L.; Katana, A.; et al. High prevalence of Abacavir-associated L74V/I mutations in Kenyan children failing antiretroviral therapy. Pediatr. Infect. Dis. J. 2017, 36, 758-760. [CrossRef] [PubMed]

5. U.S. Food \& Drug Administration. Antiretroviral Drugs Used in the Treatment of HIV Infection. Available online: https://www.fda.gov/ForPatients/Illness/HIVAIDS/Treatment/ucm118915.htm (accessed on 22 May 2018).

6. National Institute of Allergy and Infectious Disease. Drugs That Fight HIV-1. Available online: https:/ / aidsinfo.nih.gov/contentfiles/upload/HIV_Pill_Brochure.pdf (accessed on 22 May 2018).

7. DailyMed. Drug Listing Certification. Available online: https://dailymed.nlm.nih.gov/dailymed/index.cfm (accessed on 22 May 2018).

8. Reust, C.E. Common adverse effects of antiretroviral therapy for HIV disease. Am. Fam. Phys. 2011, 83, 1443-1451. 
9. Tantillo, C.; Ding, J.; Jacobo-Molina, A.; Nanni, R.G.; Boyer, P.; Hughes, S.H.; Pauwels, R.; Andries, K.; Jansen, P.A.; Arnold, E. Locations of anti-AIDS drug binding sites and resistance mutations in the three-dimensional structure of HIV-1 reverse transcriptase: Implications for mechanisms of drug inhibition and resistance. J. Mol. Biol. 1994, 243, 369-387. [CrossRef] [PubMed]

10. Pawlotsky, J. Treatment failure and resistance with direct-acting antiviral drugs against Hepatitis $\mathrm{C}$ virus. Hepatology 2011, 53, 1742-1751. [CrossRef] [PubMed]

11. Koutsoudakis, G.; Romero-Brey, I.; Berger, C.; Pérez-Vilaró, G.; Monteiro, P.P.; Vondran, F.W.R.; Kalesse, M.; Harmrolfs, K.; Müller, R.; Martinez, J.P.; et al. Soraphen A: A broad-spectrum antiviral natural product with potent anti-hepatitis C virus activity. J. Hepatol. 2015, 63, 813-821. [CrossRef] [PubMed]

12. Herrmann, J.; Fayad, A.A.; Müller, R. Natural products from myxobacteria: Novel metabolites and bioactivities. Nat. Prod. Rep. 2017, 34, 135-160. [CrossRef] [PubMed]

13. Hüttel, S.; Testolin, G.; Herrmann, J.; Planke, T.; Gille, F.; Moreno, M.; Stadler, M.; Brönstrup, M.; Kirschning, A.; Müller, R. Discovery and total synthesis of natural cystobactamid derivatives with superior activity against Gram-negative pathogens. Angew. Chem. Int. Ed. 2017, 56, 12760-12764. [CrossRef] [PubMed]

14. Gerth, K.; Bedorf, N.; Irschik, H.; Höfle, G.; Reichenbach, H. The soraphens: A family of novel antifungal compounds from Sorangium cellulosum (Myxobacteria). J. Antibiot. 1994, 47, 23-31. [CrossRef] [PubMed]

15. Reichenbach, H. Myxobacteria, producers of novel bioactive substances. J. Ind. Microbiol. Biotechnol. 2001, 27, 149-156. [CrossRef] [PubMed]

16. Gerth, K.; Pradella, S.; Perlova, O.; Beyer, S.; Müller, R. Myxobacteria: Proficient producers of novel natural products with various biological activities-Past and future biotechnological aspects with the focus on the genus Sorangium. J. Biotechnol. 2003, 106, 233-253. [CrossRef] [PubMed]

17. Dawid, W. Biology and global distribution of myxobacteria in soils. FEMS Microbiol. 2000, 24, 403-427. [CrossRef]

18. Mohr, K.I.; Moradi, A.; Glaeser, S.P.; Kämpfer, P.; Gemperlein, K.; Nübel, U.; Schumann, P.; Müller, R.; Wink, J. Nannocystis konarekensis sp. nov., a novel myxobacterium from an Iranian desert. Int. J. Syst. Evol. Microbiol. 2018, 68, 721-729. [CrossRef] [PubMed]

19. Wenzel, S.C.; Müller, R. Myxobacteria-'Microbial factories' for the production of bioactive secondary metabolites. Mol. BioSyst. 2009, 5, 567-574. [CrossRef] [PubMed]

20. Weissman, K.J.; Müller, R. Myxobacterial secondary metabolites: Bioactivities and modes-of-action. Nat. Prod. Rep. 2010, 27, 1276-1295. [CrossRef] [PubMed]

21. Korp, J.; Gurovic, M.S.V.; Nett, M. Antibiotics from predatory bacteria. Beilstein J. Org. Chem. 2016, 12, 594-607. [CrossRef] [PubMed]

22. Goldman, B.S.; Nierman, W.C.; Kaiser, D.; Slater, S.C.; Durkin, A.S.; Eisen, J.A.; Ronning, C.M.; Barbazuk, W.B.; Blanchard, M.; Field, C.; et al. Evolution of sensory complexity recorded in a myxobacterial genome. Prod. Natl. Acad. Sci. USA 2006, 103, 15200-15205. [CrossRef] [PubMed]

23. Wenzel, S.C.; Müller, R. The impact of genomics on the exploitation of the myxobacterial secondary metabolome. Nat. Prod. Rep. 2009, 26, 1385-1407. [CrossRef] [PubMed]

24. Céspedes, A.D.; Hufendiek, P.; Crüsemann, M.; Schäberle, T.F.; König, G.M. Marine-derived myxobacteria of the suborder Nannocystineae: An underexplored source of structurally intriguing and biologically active metabolites. Beilstein J. Org. Chem. 2016, 12, 969-984. [CrossRef] [PubMed]

25. Schneiker, S.; Perlova, O.; Kaiser, O.; Gerth, K.; Alici, A.; Altmeyer, M.O.; Bartels, D.; Bekel, T.; Beyer, S.; Bode, E.; et al. Complete genome sequence of the myxobacterium Sorangium cellulosum. Nat. Biotechnol. 2007, 25, 1281-1289. [CrossRef] [PubMed]

26. Schäberle, T.F.; Lohr, F.; Schmitz, A.; König, G.M. Antibiotics from myxobacteria. Nat. Prod. Rep. 2014, 31, 953-972. [CrossRef] [PubMed]

27. Bode, H.B.; Bethe, B.; Höfs, R.; Zeeck, A. Big effects from small changes: Possible ways to explore nature's chemical diversity. ChemBioChem 2002, 3, 619-627. [CrossRef]

28. Seitz, R. Human Immunodeficiency Virus (HIV). Transfus. Med. Hemother. 2016, 43, $203-222$.

29. Curreli, F.; Kwon, Y.D.; Zhang, H.; Scacalossi, D.; Belov, D.S.; Tikhonov, A.A.; Andreev, A.I.; Altieri, A.; Kurkin, A.V.; Kwong, P.D.; et al. Structure-based design of a small molecule CD4-antagonist with broad spectrum anti-HIV-1 activity. J. Med. Chem. 2015, 58, 6909-6927. [CrossRef] [PubMed] 
30. Asim, K.D.; Lin, R.; Shibo, J. Structure-based identification of small molecule antiviral compounds targeted to the gp41 core structure of the Human Immunodeficiency Virus type 1. J. Med. Chem. 1999, 42, 3203-3209.

31. Martinez, J.P.; Hinkelmann, B.; Fleta-Soriano, E.; Steinmetz, H.; Jansen, R.; Diez, J.; Frank, R.; Sasse, F.; Meyerhans, A. Identification of myxobacteria-derived HIV inhibitors by a high-throughput two-step infectivity assay. Microb. Cell Fact. 2013, 12. [CrossRef] [PubMed]

32. Zander, W.; Irschik, H.; Augustiniak, H.; Herrmann, M.; Jansen, R.; Steinmetz, H.; Gerth, K.; Kessler, W.; Kalesse, M.; Höfle, G.; et al. Sulfangolids, macrolide sulfate esters from Sorangium cellulosum. Chem. Eur. J. 2012, 18, 6264-6271. [CrossRef] [PubMed]

33. Available online: https://scifinder.cas.org/scifinder/view/scifinder/scifinderExplore.jsf (accessed on 10 July 2018).

34. Shen, Y.; Volrath, S.L.; Weatherly, S.C.; Elich, T.D.; Tong, L. A mechanism for the potent inhibition of eukaryotic acetyl-coenzyme A carboxylase by soraphen A, a macrocyclic polyketide natural product. Mol. Cell 2004, 16, 881-891. [CrossRef] [PubMed]

35. Mühlradt, P.F.; Sasse, F. Epothilone B stabilizes microtubuli of macrophages like taxol without showing taxol-like endotoxin activity. Cancer Res. 1997, 57, 3344-3346. [PubMed]

36. Goodin, S.; Kane, M.P.; Rubin, E.H. Epothilones: Mechanism of action and biologic activity. J. Clin. Oncol. 2004, 22, 2015-2025. [CrossRef] [PubMed]

37. Peterson, J.K.; Tucker, C.; Favours, E.; Cheshire, P.J.; Creech, J.; Billups, C.A.; Smykla, R.; Lee, F.Y.F.; Houghton, P.J. In vivo evaluation of Ixabepilone (BMS247550), A novel epothilone B derivative, against pediatric cancer models. Clin. Cancer Res. 2005, 11, 6950-6958. [CrossRef] [PubMed]

38. Reboll, M.R.; Ritter, B.; Sasse, F.; Niggemann, J.; Frank, R.; Nourbakhsh, M. The myxobacterial compounds spirangien A and spirangien M522 are potent inhibitors of IL-8 expression. ChemBioChem 2012, 13, 409-415. [CrossRef] [PubMed]

39. Jurkliewicz, E.; Jansen, R.; Kunze, B.; Trowitzsch-Klenast, W.; Porche, E.; Reichenbach, H.; Höfle, G.; Hunsmann, G. Three new potent HIV-1 inhibitors from myxobacteria. Antivir. Chem. Chemother. 1992, 3 , 189-193. [CrossRef]

40. Trowitzsch-Kienast, W.; Forche, E.; Wray, V.; Reichenbach, H.; Jurkiewicz, E.; Hunsmann, G.; Höfle, G. Phenalamide, neue HIV-1-Inhibitoren aus Myxococcus stipitatus Mx s40. Liebigs Ann. Chem. 1992, 1992, 659-664. [CrossRef]

41. Garcia, R.; Stadler, M.; Gemperlein, K.; Müller, R. Aetherobacter fasciculatus gen. nov., sp. nov. and Aetherobacter rufus sp. nov., novel myxobacteria with promising biotechnological applications. Int. J. Syst. Evol. Microbiol. 2016, 66, 928-938. [CrossRef] [PubMed]

42. Plaza, A.; Garcia, R.; Bifulco, G.; Martinez, J.P.; Hüttel, S.; Sasse, F.; Meyerhans, A.; Stadler, M.; Müller, R. Aetheramides A and B, potent HIV-inhibitory depsipeptides from a Myxobacterium of the new genus "Aetherobacter". Org. Lett. 2012, 14, 2854-2857. [CrossRef] [PubMed]

43. Gerth, K.; Schummer, D.; Höfle, G.; Irschik, H.; Reichenbach, H. Ratjadon: A new antifungal compound from Sorangium cellulosum (Myxobacteria) Production, physico-chemical and biological properties. J. Antibiot. 1995, 48, 787-792. [CrossRef]

44. Fleta-Soriano, E.; Martinez, J.P.; Hinkelmann, B.; Gerth, K.; Washausen, P.; Diez, J.; Frank, R.; Sasse, F.; Meyerhans, A. The myxobacterial metabolite ratjadone A inhibits HIV infection by blocking the Rev/CRM1-mediated nuclear export pathway. Microb. Cell Fact. 2014, 13, 17. [CrossRef] [PubMed]

45. ICTV. Taxonomy. Available online: https://talk.ictvonline.org/taxonomy/ (accessed on 30 April 2018).

46. Britt, W.J.; Vugler, L.; Butfiloski, E.D.; Stevens, E.B. Cell surface expression of Human Cytomegalovirus (HCMV): Use of HCMV-recombinant vaccinia virus-infected cells in analysis of the human neutralizing antibody response. J. Virol. 1990, 64, 1079-1085. [PubMed]

47. Arvin, A.M.; Alford, C.A. Chronic Intrauterine and Perinatal Infections. In Antiviral Agents and Viral Diseases of Man; Galassov, G.J., Whitley, R.J., Merigan, T.C., Eds.; Raven Press: New York, NY, USA, 1990; Volume 3, pp. 497-580.

48. Field, A.K. Human cytomegalovirus: Challenges opportunities and new drug development. Antivir. Chem. Chemother. 1999, 10, 219-232. [CrossRef] [PubMed]

49. Castro, A.; Martinez, A. Novel agents for the treatment of human cytomegalovirus infection. Exp. Opin. Ther. Pat. 2000, 10, 165-177. [CrossRef] 
50. Xiong, X.; Smith, J.L.; Chen, M.S. Effect of incorporation of Cidofovir into DNA by Human Cytomegalovirus DNA polymerase on DNA elongation. Antimicrob. Agents Chemother. 1997, 24, 594-599.

51. Boivin, G.; Chou, S.; Quirk, M.R.; Alejo, E.; Jordan, M.C. Detection of ganciclovir resistance mutations and quantitation of cytomegalovirus (CMV) DNA in leucocytes of patients with fatal disseminated CMV disease. J. Infect. Dis. 1996, 173, 523-528. [CrossRef] [PubMed]

52. Nassir, M.R.; Emerson, S.G.; Devivar, R.V.; Townsend, L.B.; Drach, J.C.; Taichman, R. Comparison of benzimidazole nucleosides ganciclovir on the in vitro proliferation and colony formation of human marrow progenitor cells. Br. J. Haematol. 1996, 93, 273-279. [CrossRef]

53. Kaul, D.R.; Stoelben, S.; Cober, E.; Ojo, T.; Sandusky, E.; Lischka, P.; Zimmermann, H.; Rübsamen-Schaeff, H. First report of successful treatment of multidrug-resistant cytomegalovirus disease with the novel anti-CMV compound AIC246. Am. J. Transpl. 2011, 11, 1079-1084. [CrossRef] [PubMed]

54. NEJM Journal Watch. Letermovir Approved to Prevent CMV Infection and Disease in Transplant Patients. Available online: https://www.jwatch.org/na45554/2017/12/07/letermovir-approved-prevent-cmvinfection-and-disease (accessed on 17 June 2018).

55. Schieferdecker, S.; König, S.; Koeberle, A.; Dahse, H.M.; Werz, O.; Nett, M. Myxochelins Target Human 5-Lipoxygenase. J. Nat. Prod. 2015, 78, 335-338. [CrossRef] [PubMed]

56. Nagoba, B.; Vedpathak, D. Medical applications of siderophores. Eur. J. Gen. Med. 2011, 8, $229-235$. [CrossRef]

57. Miyanaga, S.; Obata, T.; Onaka, H.; Fujita, T.; Saito, N.; Sakurai, H.; Saiki, I.; Furumai, T.; Igarashi, Y. Absolute configuration and antitumor activity of myxochelin a produced by Nonomuraea pusilla TP-A0861. J. Antibiot. 2006, 59, 698-703. [CrossRef] [PubMed]

58. Korp, J.; König, S.; Schieferdecker, S.; Dahse, H.M.; König, G.M.; Werz, O.; Nett, M. Harnessing enzymatic promiscuity in myxochelins biosynthesis for the production of 5-lipoxygenase inhibitors. ChemBioChem 2015, 16, 2445-2450. [CrossRef] [PubMed]

59. Schieferdecker, S.; König, S.; Simona Pace, S.; Werz, O.; Nett, M. Myxochelin-inspired 5-lipoxygenase inhibitors: Synthesis and biological evaluation. ChemMedChem 2017, 12, 23-27. [CrossRef] [PubMed]

60. Miyanga, S.; Sakurai, H.; Saiki, I.; Onaka, H.; Igarashi, Y. Synthesis and evaluation of myxochelins analogues as antimetastatic agents. Biol. Med. Chem. 2009, 17, 2724-2732. [CrossRef] [PubMed]

61. Ambrosi, H.D.; Hartmann, V.; Pistorius, D.; Reissbrodt, R.; Trowitzsch-Kienast, W. Myxochelins B, C, D, E and F: A new structural principle for powerful siderophores imitating Nature. Eur. J. Org. Chem. 1998, 541-551. [CrossRef]

62. Gaitatzis, N.; Kunze, B.; Müller, R. Novel insights into siderophore formation in myxobacteria. Chembiochem. 2005, 6, 365-374. [CrossRef] [PubMed]

63. Nadmid, S.; Plaza, A.; Lauro, G.; Garcia, R.; Bifulco, G.; Müller, R. Hyalachelins A-C, Unusual Siderophores Isolated from the terrestrial Myxobacterium Hyalangium minutum. Org. Lett. 2014, 16, 4130-4133. [CrossRef] [PubMed]

64. Kunze, B.; Trowitzsch-Kienast, W.; Hofle, G.; Reichenbach, H. Nannochelins A, B and C, new iron-chelating compounds from Nannocystis exedens (myxobacteria) production, isolation, physico-chemical and biological properties. J. Antibiot. 1991, 45, 147-150. [CrossRef]

65. Saha, M.; Sarkar, S.; Sarkar, B.; Sharma, B.K.; Bhattacharjee, S.; Prosun, T. Microbial siderophores and their potential applications: A review. Environ. Sci. Pollut. Res. 2016, 23, 3984-3999. [CrossRef] [PubMed]

66. World Health Organization. Ebola virus Disease. Available online: http://www.who.int/en/news-room/ fact-sheets/detail/ebola-virus-disease (accessed on 5 May 2018).

67. Beck, S.; Henß, L.; Weidner, T.; Herrmann, J.; Müller, R.; Chao, Y.; Weber, C.; Sliva, K.; Schnierle, S. Identification of inhibitors of Ebola virus pseudotyped vectors from a myxobacterial compound library. Antivir. Res. 2016, 132, 85-91. [CrossRef] [PubMed]

68. Kunze, B.; Jansen, R.; Sasse, F.; Höflen, G.; Reichenbach, H.; Chondramides, A.D. New antifungal and cytostatic depsipeptides from Chondromyces crocatus (Myxobacteria). Production, physico-chemical and biological Properties. J. Antibiot. 1995, 48, 1262-1266. [CrossRef] [PubMed]

69. Reichenbach, H. Myxobacteria: A source of new antibiotics. Trends Biotechnol. 1988, 6, 115-121. [CrossRef] 
70. Barbier, J.; Jansen, R.; Irschik, H.; Benson, S.; Gerth, K.; Böhlendorf, B.; Höfle, G.; Reichenbach, H.; Wegner, J.; Zeilinger, C.; et al. Isolation and total synthesis of icumazoles and noricumazoles-Antifungal antibiotics and cation-channel blockers from Sorangium cellulosum. Angew. Chem. Int. Ed. 2012, 51, 1256-1260. [CrossRef] [PubMed]

71. Sasse, F.; Steinmetz, H.; Heil, J.; Höfle, G.; Reichenbach, H. Tubulysins, new cytostatic peptides from Myxobacteria acting on microtubuli. Production, isolation, physico-chemical and biological properties. J. Antibiot. 2000, 53, 879-885. [CrossRef] [PubMed]

72. El-Serag, H.B. Epidemiology of viral hepatitis and hepatocellular carcinoma. Gastroenterology 2012, 142, 1264-1273. [CrossRef] [PubMed]

73. World Health Organization. Hepatitis C. Available online: http://www.who.int/en/news-room/factsheets / detail/hepatitis-c (accessed on 10 May 2018).

74. Shepard, C.W.; Finelli, L.; Alter, M.J. Global epidemiology of hepatitis C virus infection. Lancet Infect. Dis. 2005, 5, 558-567. [CrossRef]

75. Mulwa, L.; Jansen, R.; Praditya, D.; Mohr, K.; Wink, J.; Steinmann, E.; Stadler, M. Six heterocyclic metabolites from the Myxobacterium Labilithrix luteola. Molecules 2018, 23, 542. [CrossRef] [PubMed]

76. Bedorf, N.; Schomburg, D.; Gerth, K.; Reichenbach, H.; Höfle, G.; Bedorf, N.; Schomburg, D.; Gerth, K.; Reichenbach, H.; Höfle, G. Isolation and structure elucidation of soraphen $\mathrm{A}_{1 \alpha}$, a novel antifungal macrolide from Sorangium cellulosum. Liebigs Ann. Chem. 1993, 1993, 1017-1021. [CrossRef]

77. Singaravelu, R.; Desrochers, G.F.; Srinivasan, P.; O’Hara, S.; Lyn, R.; Müller, R.; Jones, D.M.; Russell, R.; Pezacki, J.P. Soraphen A: A probe for investigating the role of de novo lipogenesis during viral infection. ACS Infect. Dis. 2015, 1, 130-134. [CrossRef] [PubMed]

78. Gentzsch, J.; Hinkelmann, B.; Kaderali, L.; Irschik, H.; Jansen, R.; Sasse, F.; Frank, R.; Pietschmann, T. Hepatitis $C$ virus complete life cycle screen for identification of small molecules with pro- or antiviral activity. Antiviral Res. 2011, 89, 136-148. [CrossRef] [PubMed]

79. Mulwa, L.S.; Jansen, R.; Praditya, D.F.; Mohr, K.I.; Okanya, P.W.; Wink, J.; Steinmann, E.; Stadler, M. Lanyamycin, a macrolide antibiotic from Sorangium cellulosum, strain Soce 481 (Myxobacteria). Beilstein J. Org. Chem. 2018, 14, 1554-1562. [CrossRef] [PubMed]

80. Yeganeh, B.; Ghavami, S.; Kroeker, A.L.; Mahood, T.H.; Stelmack, G.L.; Klonisch, T.; Coombs, K.M.; Halayko, A.J. Suppression of influenza A virus replication in human lung epithelial cells by noncytotoxic concentrations bafilomycin A1. Am. J. Physiol. Lung Cell. Mol. Physiol. 2015, 308, 270-286. [CrossRef] [PubMed]

81. Hoffmann, T.; Krug, D.; Bozkurt, N.; Duddela, S.; Jansen, R.; Garcia, R.; Gerth, K.; Steinmetz, H.; Müller, R. Correlating chemical diversity with taxonomic distance for discovery of natural products in myxobacteria. Nat. Commum. 2018, 9, 803. [CrossRef] [PubMed]

(c) 2018 by the authors. Licensee MDPI, Basel, Switzerland. This article is an open access article distributed under the terms and conditions of the Creative Commons Attribution (CC BY) license (http://creativecommons.org/licenses/by/4.0/). 